\title{
Utilization of Satellite Landsat-8 Operational Land Imager (OLI) for Land Cover Classification Nutmeg Plantation In Tapaktuan Sub-District
}

\author{
Safridatul 'Audaha.1.*Nazliyatib \\ Industrial Engineering Departermet, Polytechnics of Aceh Selatan \\ Komplek Reklamasi Pantai. JL. Mardeka, Tapaktuan 23713, Indonesia \\ 1E-mail: Safridatul@yahoo.co.id*
}

Article history:

Received

Keywords:

Landsat-8 OLI

Classification

Remote Sensing

Land Cover

Nutmeg Plantation

\begin{abstract}
This research seeks to utilize technology remote sensing with satellite Landsat 8 OLI imagery by classification method to obtain the area of land cover used for nutmeg plantations in Tapaktuan Sub District. Several stages of image data processing methods have been done such as geometric correction of images, image cropping and image clsification.The result of geometric correction of image obtained RMS error of 0.011235 pixel, The geometric correction process has met the tolerance limit error $>1$ pixel. As for the results of classification processing image Landsat-8 OLI year 2017 in Tapaktuan sub-district produce 6 classes land cover of nutmeg garden, mixed florest blantations, water, protected forest, settlement, and open land, the of classification results obtained by plantation area of nutmeg $4.72 \%$, Based on the calculation of confusion matrix then obtained the overall accurasy value of $97.5714 \%$ and kappa accurasy of $96.55 \%$. The result of classification accuracy test shows high accuracy and fulfill the requirement set by USGS (> 85\%). This result shows that the map of Landsat- 8 OLI image classification can be used as a material in determining the location of nutmeg plantation distribution.
\end{abstract}

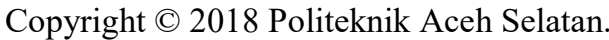
All rights reserved.

\section{Introduction}

Tapaktuan is the western coastal area of Aceh is known as the area where the plant spices, one of which is a nutmeg plant that thrives and has economic value and multipurpose because every part of the plant can be utilized in various industries, such as food and beverage industries that serve as a source community income in South Aceh, especially in Tapaktuan sub-district.

Nutmeg is known as a spice plant that has economic value and multipurpose because every part of the plant can be utilized in various industries. Seeds, mace and nutmeg oil are export commodities and used in the food and beverage industry. One part of the nutmeg is the nutmeg. This nutmeg meat can be processed into several kinds of products such as candied nutmeg, dodol nutmeg, nutmeg aseman, nutmeg, nutmeg and nutmeg syrup [7]. Tapaktuan City is a producing region and produce its own processed products from nutmeg. In this area of nutmeg plants is a local superior crop, because the plant is cultivated in every district.

Monitoring of nutmeg plantations in terrestris / field alone will take a long time and energy is not small. Besides, limited field observation because the location is often difficult to reach because of its topography condition. The nutmeg plantations are not visible thoroughly in the field, due to human limitations to see the parts that are protected by hills and valleys. Therefore, plantation monitoring can be done by remote sensing method that is based on the interpretation of remote 
sensing image enclosure that can provide spatial data, fast and accurate spectral, and this technique has also been done [5].

Remote sensing is a technique for gathering information about the object and its environment obtained from images at a distance without physical touch. The objective is to collect data on natural and environmental resources, such as identifying land cover [1]. Remote sensing has long been an important and effective means of monitoring land cover with the ability to provide information on the spatial diversity on the surface of the earth quickly, widely, precisely and easily [4][6].

This remote sensing method typically utilizes satellite images such as Landsat imagery. On February 11, 2013, Landsat Data Continuity Mission (LDCM), which is known as Landsat-8, has 2 sensors. The Land Imager (OLI) operational sensor consists of 9 channels (band) including highresolution panchromatic bands and Thermal Infra Red Sensor (TIRS) with 2 thermal bands. Landsat satellite data is usually used in remote sensing for land cover classification [3], so the latest land cover map can be obtained easily.

Grouping classes into informational classes and spectral classes. Informational classes are classes defined directly by users, such as classes on land cover and land use in general [2]. Classification of land cover / use is the effort to group different types of land cover / land use into one similarity in accordance with a particular system. Classification of land cover is used as a guide or reference in the process of interpretation of remote sensing imagery for the purpose of mapping land cover / land use [8]. some classification system of land cover / land use that has been developed, which is motivated by a particular interest or at a certain time. One classification of land cover that will be used in this research is to know the area of land use of nutmeg plantation.

\section{Method}

The research was conducted in Tapaktuan sub-district, which is the capital of South Aceh district located at $02^{\circ} 23^{\prime} 24^{\prime \prime}-03^{\circ} 44^{\prime} 24^{\prime \prime}$ LU and 96 ${ }^{\circ} 57^{\prime} 36^{\prime \prime}-97^{\circ} 56^{\prime} 24^{\prime \prime}$ BT.

To know the extent of nutmeg plantations and other land cover, it is necessary to image satellite imagery landsat-8 OLI Year 2017 with the assumption that all channels in the image is still good for use in research that is testing the pixel value. The stages of the scheme in this study can be illustrated as presented in Figure 1.

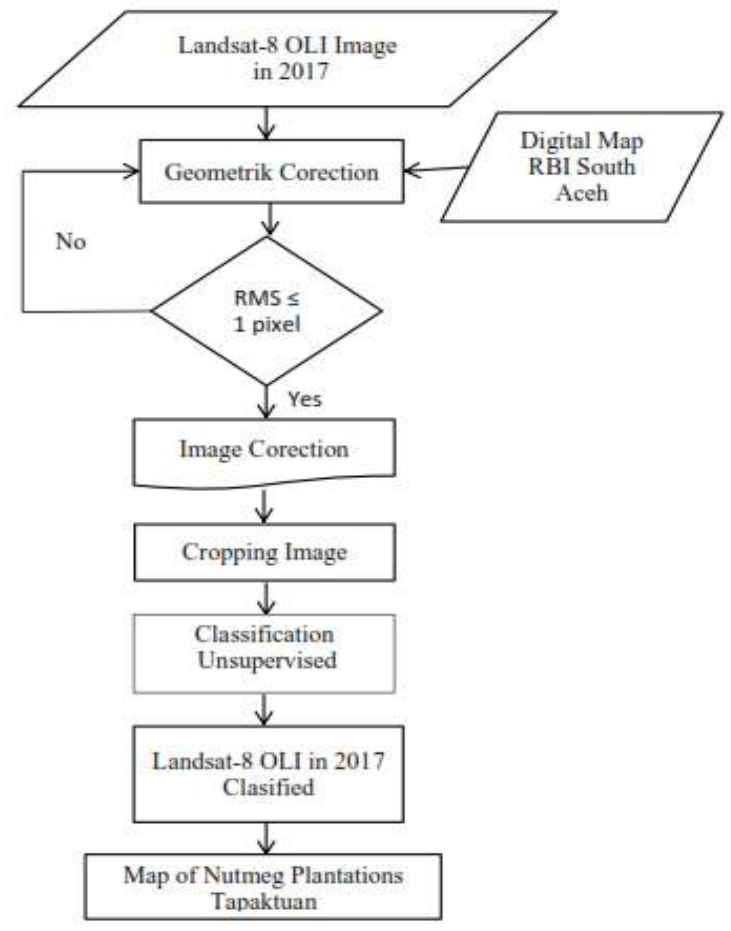

Figure 1. Flow Chart of Research 


\section{Results and Discussion}

\section{A. Geomterik Corektion}

Geometric correction is a process for correcting geometric errors in digital image pixels. Because the source of geometric errors is caused by the rotation of the earth, the curvature of the earth, changes in the height of the rides, the speed, and the change of the position of the rides. The image is corrected by image to image by using the vector map of Tapaktuan subdistrict from the result of digitized map of RBI For geometric accuracy test, RMSE (Root Mean Square Error) is used with an average RMSE value of image less than equal to one (RMSE $=1$ ) pixel If the RMSE value is greater than one (RMSE $>1)$ then geometric correction must be performed again, until the RMSE value is less than equal to one $(\mathrm{RMSE}=1)$

Table.1. RMS error Image Landsat-8 OLI in 2017

\begin{tabular}{|c|c|c|c|c|c|c|c|c|c|}
\hline Point & Base X & Base Y & Warp X & Warp Y & Predict X & Predict Y & Error X & Error Y & RMS \\
\hline 1 & 2941,47 & 674,87 & 2941,30 & 674,85 & 2941,2960 & 674,8500 & $-0,0040$ & 0.0009 & 0,0040 \\
\hline 2 & 4404,06 & 987,82 & 4404,06 & 987,82 & 4404,0622 & 987,8146 & 0,0022 & $-0,0054$ & 0,0059 \\
\hline 3 & 5099,22 & 1897,26 & 5099,21 & 1897,24 & 5099,2231 & 1897,2482 & 0,0131 & 0,0082 & 0,0155 \\
\hline 4 & 5772,12 & 2633,42 & 5772,10 & 2633,4 & 5772,0797 & 2633,3965 & $-0,0203$ & $-0,0035$ & 0,0206 \\
\hline 5 & 6375,29 & 3677,47 & 6375,10 & 3677,42 & 6375,1089 & 3677,4211 & 0,0011 & 0,0011 & 0,0089 \\
\hline 6 & 1332,47 & 4350,63 & 1332,47 & 4350,63 & 1332,4751 & 4350,6342 & 0,0051 & 0,0042 & 0,0066 \\
\hline 7 & 2261,68 & 5087,74 & 2261,68 & 5087,74 & $2.261,6749$ & $5.087,7354$ & $-0,0051$ & $-0,0046$ & 0,0068 \\
\hline
\end{tabular}

From Table. 1. Coordinate GCP Image Landsat- 8 OLI Year 2017 obtained RMS error overall that is 0.011235 . The geometric correction process in this image meets the tolerance that geometric correction error limits are less than 1 pixel.

\section{B. Cropping Image}

After the geometric process is done, then in the continuity of the cutting the image is used to focus more data processing in accordance with the research area so that more focused data processing, the image is cut with the administrative boundary map of Tapaktuan region. The result of image cutting can be seen in Figure 2.

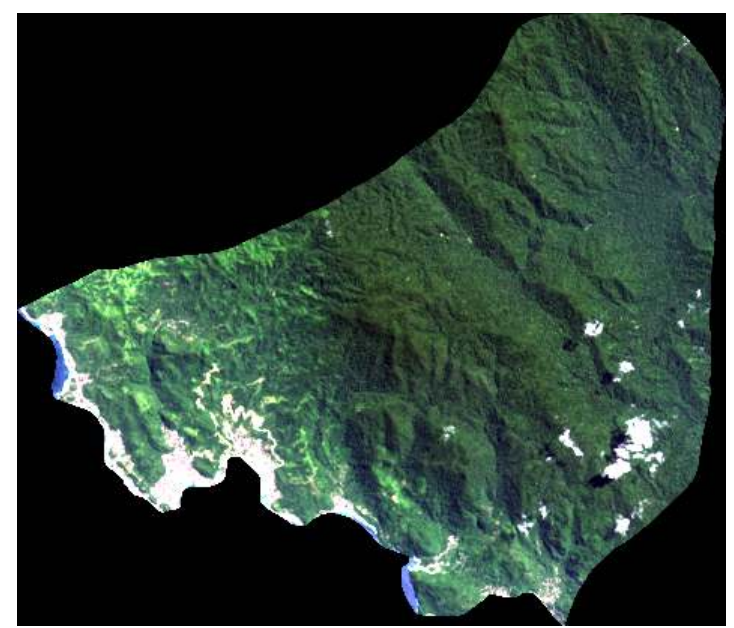

Figure 2. Result Cropping Landsat-8 OLI Image 


\section{Classification Of Land Cover Tapaktuan Sub-District.}

One of the important factors in determining the mapping of nutmeg plantations in the Tapaktuan region lies in the selection of classification methods. Image classification is the process of dividing pixels into a particular class. The result of classification processing on Landsat-8 OLI image of Year 2017 produces the classified image as seen in Fig.3, where the classification results are divided into 6 classes of land cover covering nutmeg plantation, mixed nutmeg, water body, protection forest, settlement, and land open.

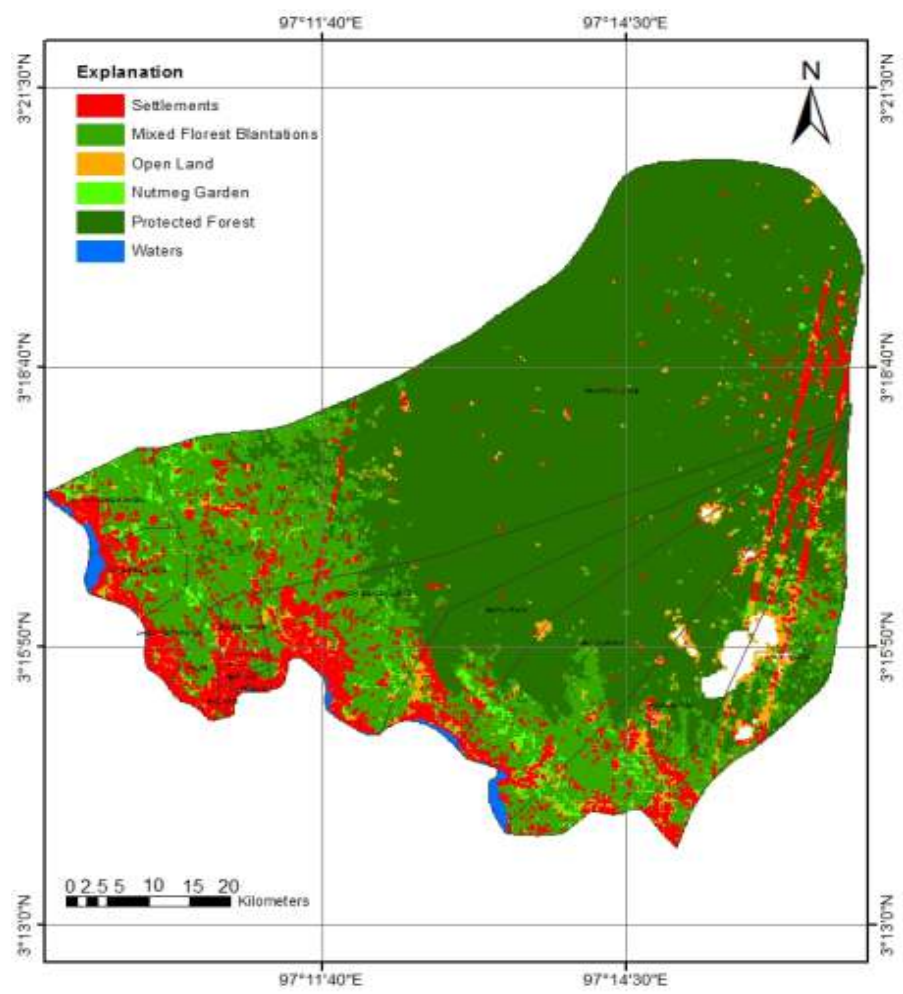

Figure 3. Result Classification Landsat-8 OLI Image in 2017

After the classification process was done on the OLI landsat-8 image, the land cover classification map was found in Tapaktuan sub-district along with the width of each land cover class. The extent and distribution of nutmeg plantations and land cover classes can be presented in Table 4 .

Table 4. Results classification of land cover Tapaktuan Sub-Distrik using Landsat 8

\begin{tabular}{|c|c|c|}
\hline Class Land Cover & Area $\left(\mathbf{K m}^{2}\right)$ & $\begin{array}{c}\text { Persentase } \\
(\%)\end{array}$ \\
\hline Water & 728100 & 0,70 \\
\hline Protected Forest & 67320900 & 65,23 \\
\hline Settlements & 7278300 & 7,06 \\
\hline Open Land & 4335300 & 4,2 \\
\hline Mixed Florest Blantations & 18668700 & 18,09 \\
\hline Nutmeg Garden & 4874400 & 4,72 \\
\hline Total & 103205700 & 100 \\
\hline
\end{tabular}

Based on the classification, land cover in 2017 in Tapaktuan sub-district is dominated by protected forest area of $65.23 \%$, then followed by a mixed forest nutmeg area of $18.09 \%$,whereas for nutmeg cultivation plants obtained an area of $4.72 \%$. Evident from the mapping results obtained that the forest area in the region Tapaktuan have a high area compared with the extent of other classes. After classification for land cover, the results of the classification should be tested for accuracy. The classification test in this research uses confusion matrix where the result of the 
classification test should be $=80 \%$ so that the classification result is considered correct. Image 2017 can be seen in Table 2 and Table 3.

Table 2. Calculation Results Confusion Matrix Landsat-8 OLI in 2017

\begin{tabular}{|l|c|c|c|c|c|c|c|}
\hline \multicolumn{1}{|c|}{ Class } & $\mathbf{1}$ & $\mathbf{2}$ & $\mathbf{3}$ & $\mathbf{4}$ & $\mathbf{5}$ & $\mathbf{6}$ & Total \\
\hline Waters & 233 & 0 & 0 & 0 & 0 & 0 & 233 \\
\hline Protected Forest & 0 & 285 & 0 & 0 & 0 & 0 & 285 \\
\hline Settlements & 0 & 0 & 70 & 0 & 0 & 0 & 70 \\
\hline Open Land & 2 & 0 & 11 & 39 & 0 & 0 & 52 \\
\hline Mixed Florest Blantations & 0 & 0 & 0 & 0 & 22 & 2 & 24 \\
\hline Nutmeg Garden & 0 & 0 & 0 & 0 & 2 & 34 & 36 \\
\hline \multicolumn{1}{|c|}{ Total } & 235 & 285 & 81 & 39 & 24 & 36 & \\
\hline
\end{tabular}

Table 3. Results Commision, Ommision, Producer Accuracy, and User Accuracy Land Use

\begin{tabular}{lcccc}
\hline \multicolumn{1}{c}{ Class } & $\begin{array}{c}\text { Commision } \\
\mathbf{( \% )}\end{array}$ & $\begin{array}{c}\text { Omission } \\
\mathbf{( \% )}\end{array}$ & $\begin{array}{c}\text { Producer } \\
\text { accuracy (\%) }\end{array}$ & $\begin{array}{c}\text { User } \\
\text { accuracy } \\
(\mathbf{\%})\end{array}$ \\
\hline Waters & 0,00 & 0,85 & 99,15 & 100,00 \\
Protected Forest & 0,00 & 0,00 & 100,00 & 100,00 \\
Settlements & 0,00 & 13,58 & 86,42 & 100,00 \\
Open Land & 25,00 & 0,00 & 100,00 & 75,00 \\
Mixed Florest Blantations & 8,33 & 8,33 & 91,67 & 91,67 \\
Nutmeg Garden & 5,56 & 5,56 & 94,44 & 94,44 \\
\hline
\end{tabular}

According to the United States Geological Survey (USGS) has established the level of accuracy of classification or minimum interpretation by using remote sensing that is less than $85 \%$. Based on the calculation of confusion matrix then obtained the overall accurasy value of $97.5714 \%$ and kappa accurasy of $96.55 \%$. The result of classification accuracy test shows high accuracy and fulfill the requirement set by USGS ( $>85 \%$ ). This result shows that Landsat 8 image classification map can be used one of them as material in determining the location of nutmeg plantation distribution.

\section{Conclusion}

The conclusions of the research results are:

1. Monitoring of nutmeg plantations can be done by remote sensing methods from the satellite Image Landsat-8 OLI because satellite image monitoring is the only effective way of measuring a relatively large area.

2. Result of oli landsat-8 image classification processing year 2017 in Tapaktuan sub-district produce 6 classes land cover of nutmeg garden, mixed florest blantations, water, protected forest, settlement, and open land, the of classification results obtained by plantation area of nutmeg $4.72 \%$, where as for the results of classification accuracy test shows a high accuracy and meet the requirements set by USGS ( $>85 \%$ ). This result shows that the map of Landsat8 OLI image classification can be used as a material in determining the location of a plant nutmeg.

\section{Acknowledgment}

On this occasion the authors would like to thank the Kemenristek Diktik who has funded the completion of this research as well as a thank you also delivered to the Industrial Engineering Departermet, Polytechnic of Aceh Selatan that has provided space and time for research. 


\section{References}

[1] Campbell B. James., Introduction To Remote Sensing, The Guilford Press., New York., 1994.

[2] Campbell, J.B. Introduction to Remote Sensing. (Third Edition). The Guilford Press. New York., 2002.

[3] Gumma MK, Thenkabail PS, Hideto F, Nelson A, Dheeravath V, Busia D, Rala A., Mapping irrigated areas of Ghana using fusion of $30 \mathrm{~m}$ and $250 \mathrm{~m}$ resolution remote sensing data. Remote Sensing. 3: 816835., 2011.

[4] Hansen MC, Defries RS, Townshend JRG, Sohlberg R., Global land cover classification at $1 \mathrm{~km}$ spatial resolution using a classification tree approach. International Journal of Remote Sensing. 21: 1331-1364., 2000

[5] Hardiyanti, F. S., Grandharum, K. T. L. dan Rambo., Pemantauan Kerusakan Lingkungan Wilayah Meratus, Kalimantan Selatan Dari Citra Landsat-TM Dengan Kajian Geografis, PP. 50-63., 2006.

[6] Liu JY, Zhuang DF, Luo D, Xiao X., Land-cover classification of China: integrated analysis of AVHRR imagery and geophysical data. International Journal of Remote Sensing. 24:2485-2500., 2003.

[7] Nurdjannah, N., Teknologi Pengolahan Pala, Badan Penelitian dan Pengembangan Pertanian, 2007.

[8] Sitous, J. Dkk., Kajian Model Deteksi Perubahan Pentupan Lahan Menggunakan Data Inderaja Untuk Aplikasi Perubahan Lahan Sawah. PUSBANGJA LAPAN., (2006).

[9] USGS., LANDSAT 8 (L8) DATA USERS HANDBOOK. Department of the Interior U.S. Geological Survey. 